\title{
KOMBINASI K-MEANS DAN SUPPORT VECTOR MACHINE (SVM) UNTUK MEMPREDIKSI UNSUR SARA PADA TWEET
}

\author{
Wiga Maulana Baihaqi*1, Muliasari Pinilih ${ }^{2}$, Miftakhul Rohmah ${ }^{3}$ \\ ${ }^{1}$ Teknologi Informasi, Universitas Amikom Purwokerto \\ ${ }^{2,3}$ Sistem Informasi, Universitas Amikom Purwokerto \\ Email: ${ }^{1}$ wiga@amikompurwokerto.ac.id, ${ }^{2}$ mpinilih@amikompurwokerto.ac.id, ${ }^{3}$ m.miftakhul.mi@gmail.com \\ *Penulis Korespondensi
}

(Naskah masuk: 25 Juni 2019, diterima untuk diterbitkan: 22 April 2020)

\begin{abstract}
Abstrak
Tulisan yang disampaikan melalui twitter dinamakan dengan tweets atau dalam bahasa indonesia lebih dikenal dengan kicau, tulisan yang dishare memiliki batas maksimum, tulisan tidak boleh lebih dari 140 karakter, karakter disini terdiri dari huruf, angka, dan simbol. Penyalahgunaan dalam berpendapat sering terjadi di media sosial, sering kali pengguna media sosial dengan sadar atau tidak sadar telah membuat konten yang mengandung isu Suku (dalam hal ini menyangkut keturunan), agama, ras (kebangsaan) dan antargolongan (SARA). Perlu adanya analisis yang dapat mengidentifikasi secara otomatis apakah kalimat yang ditulis pada media sosial mengandung unsur SARA atau tidak, akan tetapi korpus tentang kalimat yang mengandung unsur SARA belum ada, selain itu label kalimat yang menandakan kalimat SARA atau bukan tidak ada. Penelitian ini bertujuan untuk membuat corpus kalimat yang mengandung unsur SARA yang didapatkan dari twitter, kemudian melabeli kalimat dengan label mengandung unsur SARA dan tidak, serta melakukan sentiment klasifikasi. Algoritme yang digunakan untuk proses pelabelan adalah k-means, sedangkan Support Vector Machine (SVM) digunakan untuk proses klasifikasi. Hasil yang diperoleh berdasarkan k-means antara lain 118 tweet positif SARA dan 83 tweet negatif SARA. Dalam proses klasifikasi menggunakan dua metode validasi, yaitu 5-fold cross validation yang dibandingkan dengan 10-fold cross validation, hasil akurasi dari kedua metode validasi tersebut yaitu, masing-masing $64,18 \%$ dan $63,68 \%$. Berdasarkan hasil akurasi yang diperoleh untuk meningkatkan hasil akurasi, data hasil proses k-means diolah kembali dengan validasi pakar bahasa, hasil yang diperoleh menjadi 139 tweet positif SARA dan 62 tweet negatif SARA, hasil akurasi meningkat menjadi 70,15\% dan 71,14\%. Dari hasil yang didapatkan, twitter dapat dijadikan sumber untuk membuat corpus mengenai kalimat SARA, dan metode yang diusulkan berhasil untuk proses pelabelan dan sentimen klasifikasi, akan tetapi masih perlu peningkatan hasil akurasi.
\end{abstract}

Kata kunci: twitter, $k$-means, support vector machine, SARA

\section{K-MEANS AND SUPPORT VECTOR MACHINE (SVM) COMBINATION TO PREDICT SARA ELEMENTS ON TWEET}

\begin{abstract}
Posts sent via twitter are called tweets or in Indonesian better known as chirping, the posts shared have a maximum limit, the writing cannot be more than 140 characters, the characters here consist of letters, numbers, and symbols. Broadcasting in discussions that often occur on social media, often users of social media consciously or unconsciously have created content that contains issues of ethnicity, religion, race (nationality) and intergroup (SARA). Obtained from the analysis that can automatically contain sentences on social media containing no SARA or not, but the corpus about sentences containing SARA does not yet exist, other than that the sentence label indicates SARA or no sentence. This study aims to make sentence corpus containing SARA elements obtained from twitter, then label sentences with labels containing elements of SARA and not, and conduct group sentiments. The algorithm used for the labeling process is k-means, while Support Vector Machine (SVM) is used for the classification process. The results obtained based on k-means include 118 positive SARA tweets and 83 negative SARA tweets. In the classification process using two validation methods, namely cross-fold validation of 5 times compared with 10-fold cross validation, the accuracy of the two validation methods is $64.18 \%$ and $63.68 \%$, respectively. Based on the results obtained to improve the results, the $k$-means process data were reprocessed with linguists, the results obtained were 139 positive SARA tweets and 62 SARA negative tweets, the results of which increased to $70.15 \%$ and $71.14 \%$. From the results obtained,
\end{abstract}


Twitter can be used as a source to create a corpus about SARA sentences, and methods that have succeeded in labeling and classification sentiments, but still need to improve the results of accuracy.

Keywords: twitter, $k$-means, support vector machine, SARA

\section{PENDAHULUAN}

Media sosial dalam perkembangan teknologi informasi memiliki andil besar bagi manusia dalam memberikan kemudahan untuk bersosialisasi. Media sosial merupakan media yang dapat diakses secara langsung melalui internet, artinya masyarakat yang menggunakan media tersebut dapat melakukan berbagai aktivitas seperti sharing (berbagi), participating (berpartisipasi) dan creating (membuat) konten-konten seperti wiki, forum, blog, dan jejaring sosial lainnya. Tentu saja semua ini tak terlepas dari kemajuan teknonologi melalui aplikasiaplikasi yang tersedia di internet (Tim Pusat Humas Kementerian Perdagangan RI, 2014).

Menurut (Hootsuite dan We Are Social, 2018) dilihat dari lama pengaksesannya, pengguna internet di Indonesia memenfaatkan waktu untuk berselancar di dunia maya selama 8,85 jam, hal tersebut belum termasuk untuk berselancar di jejaring sosial yang biasanya memakan waktu selama 3,38 jam dalam 24 jam. Sedangkan dilihat dari jumlah pengguna, perbandingan penguna internet dengan seluruh jumlah penduduk di Indonesia adalah 1:2, artinya setengah dari jumlah penduduk di Indonesia merupakan pengguna internet, 130 juta diantaranya pengguna aktif media sosial dengan penetrasi 49 persen. Merebaknya situs media sosial yang muncul banyak mendorong pada hal-hal baru sehingga bermanfaat bagi kehidupan manusia menjadi lebih mudah, efektif dan efisien. Penggunaan media sosial di Indonesia seperti pada Gambar 1.

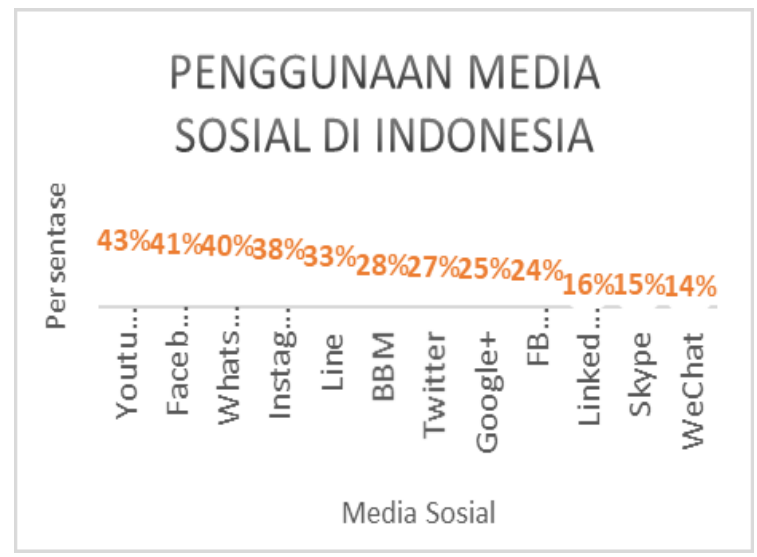

Sumber : (Hootsuite dan We Are Social, 2018)

Gambar 1. Penggunaan Media Sosial di Indonesia

Gambar 1 menunjukkan aplikasi media sosial yang digunakan oleh masyarakat Indonesia (Hootsuite dan We Are Social, 2018), Youtube menempati posisi pertama dengan persentase $43 \%$, posisi ke dua Facebook dengan persentase $41 \%$, posisi ke tiga Whatsapp dengan persentase $40 \%$, posisi ke empat Instagram dengan persentase 38\%, posisi ke lima Line dengan persentase $33 \%$, posisi ke enam BBM dengan persentase $28 \%$, posisi ke tujuh Twitter dengan persentase $27 \%$, dan lain-lain.

Tulisan yang disampaikan melalui twitter dinamakan dengan tweets atau dalam bahasa indonesia lebih dikenal dengan kicau, tulisan yang dishare memiliki batas maksimum, tulisan tidak boleh lebih dari 140 karakter, karakter disini terdiri dari huruf, angka, dan simbol (Tim Pusat Humas Kementerian Perdagangan RI, 2014). Menurut data di situs Semiocast 30 Juli 2012, semiocast telah menganalisis 517 juta profil pengguna twitter yang dibuat sebelum 1 Juli 2012. Indonesia menempati posisi ke lima dunia dengan jumlah tweet sebanyak 29,4 juta orang. Jakarta menempatkan kota paling aktif jumlah tweet yang di-posting dengan teknologi semiocast, $27 \%$ dari semua tweet geo-lokasi disemua kota. Lebih dari $2 \%$ dari semua tweet diposting di ibukota Indonesia. Aktifnya penggunaan twitter di Indonesia pengguna memiliki kebebasan berpendapat dalam menyampaikan opini, membagikan informasi yang kini sering digunakan untuk mengkritik masyarakat hingga menyampaikan kritik kepada pimpinan daerah.

Suku (dalam hal ini menyangkut keturunan), agama, ras (kebangsaan) dan antargolongan (SARA) merupakan masalah yang sering terjadi di masyarakat. SARA terjadi akibat adanya kebebasan dalam berpendapat namun kebebasan ini disalahgunakan sehingga menyinggung pihak-pihak tertentu yang termasuk dalam SARA tersebut. Akibat yang terjadi adalah munculnya kriminalitas seperti tindak kekerasan, diskriminasi dan pelecehan (Rudybyo, 2011). Penyalahgunaan dalam berpendapat sering terjadi di media sosial, sering kali pengguna media sosial dengan sadar atau tidak sadar telah membuat konten yang mengandung isu Suku (dalam hal ini menyangkut keturunan), agama, ras (kebangsaan) dan antargolongan (SARA). Sehingga Kementrian Komunikasi dan Informatika (Kementerian Komunikasi dan Informatika, 2017) pada tahun 2017 dapat merekap kasus konten di media sosial yang mengandung unsur ketidaksukaan terhadap pihak atau golongan tertentu sebanyak 13.829, selain itu terdapat 6.973 yang mengandung konten tidak sesuai dengan fakta yang ada.

Analisis sentimen atau opinion mining merupakan suatu bidang studi yang mengacu secara luas berdasarkan komputasi linguistik, text mining dan pengolahan bahasa alami yang bertujuan untuk menganalisa pendapat, sikap, emosi, penilaian, sentimen serta evaluasi seseorang yang didasarkan 
apakah pembicara atau penulis berkenan dengan suatu layanan, organisasi, individu, tokoh publik, acara ataupun kegiatan lain (Liu, 2012).

Pada umumnya, sentimen analisis terdiri dari tiga langkah utama: feature extraction, sentiment clustering, dan sentiment classification. Feature extraction merupakan langkah untuk memperoleh fitur pada data berupa teks yang tidak terstruktur. Kemudian sentiment clustering dilakukan untuk mengelompokan teks yang sejenis, ini dilakukan apabila data yang digunakan belum memiliki label atau class. Begitu juga dengan data yang akan digunakan dalam penelitian ini, data yang digunakan pada penelitian ini adalah kalimat yang mengandung unsur SARA, data tersebut tidak memiliki label bahkan belum terdapat korpus.

Pelabelan k-means telah menjadi salah satu algoritme pengelompokan yang paling mudah beradaptasi selama bertahun-tahun. Keunggulan dengan efisiensi tinggi dan kemampuan menangani dimensi tinggi menjadikan algoritme k-means pilihan yang tepat untuk analisis sentimen. Biasanya, rentang nilai antara 3 dan 7 dipilih untuk jumlah cluster (Han, Kamber \& Pei, 2012; Muzakir, 2014). Penelitian (Xu dan Tian, 2015; Mustakim, 2012) menunjukkan k-means memiliki kompleksitas waktu yang relatif rendah $(\mathrm{O}(\mathrm{nkd}))$ yang menunjukkan kinerja yang lebih cepat. Ini juga bekerja dengan baik dengan kumpulan data besar. Padahal itu cukup sensitif terhadap data yang tidak bersih. Dengan pertimbangan profesional, para peneliti menyimpulkan bahwa ini akan menjadi pendekatan yang baik. Penelitian terbaru (Korovkinas, Danėnas \& Garšva, 2019; Garay, Yap \& Sabellano, 2019; Liu dan Lee, 2018) juga menggunakan k-means untuk proses labeling teks sebelum proses sentiment classifications.

Setelah mendapatkan label dari masing-masing text, langkah selanjutnya biasanya proses klasifikasi. Support Vector Machine atau lebih sering disebut dengan SVM merupakan algoritme yang sering kali digunakan oleh peneliti untuk proses mengklasifikasikan data berupa text, SVM dapat dengan baik membedakan kelas atau label yang dimiliki oleh masing-masing text (Prasetyo, 2014). Sebuah studi empiris tentang perbandingan antara lima pendekatan pembelajaran yang diawasi membuktikan SVM menjadi pilihan yang menguntungkan untuk kerangka kerja yang diusulkan. SVM adalah penggolong linier dengan mengubah representasi fitur yang dinormalisasi menjadi vektor, koefisien linier dengan dimensi yang sama dalam ruang fitur menggunakan prediktor linier (hyperplane) (Medhat, Hassan \& Korashy, 2014). Inti dari SVM adalah untuk mentransfer data dimensi tinggi ke vektor dimensi rendah. Di bidang analisis sentimen, SVM adalah salah satu pendekatan pembelajaran mesin yang paling mudah beradaptasi.
Terbukti bahwa dalam penelitian (Rahmawati, Marjuni \& Zeniarja, 2017), k-means dan SVM digunakan untuk menganalisis pendapat dari pengguna media sosial twitter mengenai terselenggaranya pemilihan kepala daerah yang dilaksanakan secara bersama-sama, hasil yang diperoleh menunjukkan bahwa $82 \%$ algoritme yang digunakan dapat memprediksi pendapat pengguna sosial twitter dengan tepat. Penggunaan algoritme kmeans dan SVM juga dibuktikan oleh penelitian (Somantri, Wiyono dan Dairoh, 2016), kombinasi metode tersebut terbukti lebih akurat dibandingkan hanya menggunakan algoritme SVM dalam membantu mahasiswa dalam memilih tema skripsi.

Dari permasalahan yang ada dan beberapa penelitian terdahulu menganai analisis sentimen dan klasifikasi data berupa teks, maka penelitian ini akan mengumpulkan korpus mengenai kalimat dari twitter yang mengandung unsur SARA. Dan pada penelitian ini mengusulkan metode k-means untuk proses labeling dan SVM dalam proses klasifikasi apakah konten pada twitter memiliki unsur SARA atau tidak.

\section{METODE PENELITIAN}

\subsection{Dataset}

Dalam penelitian ini data yang digunakan adalah tweet berbahasa Indonesia yang menyinggung unsur SARA. Contoh data tweet yang digunakan sebagai berikut:

Tabel 1. Data Tweet Tweet

Isu sara atau blunder mulut gubernur sebelumnya? Di Solo non muslim bisa jadi walikota di Kalbar non muslim juga jadi gubernur. Sebagai warga DKI Jakarta saya jengah dengan tuduhan isu sara.

Target liberal untuk membolehkan orang kafir memimpin di wilayah mayoritas umat muslim \#propagandaliberal

2-mk mohon ahok tidak arogan dalam memerintah. Kasihan dengan cina2 lainnya yang miskin, baik dan tidak salah jika mereka jadi korban.

Oleh karena itu, Quran bukan kitab suci bukan pula menyebabkan kita tahu untuk menggaulinya. Nabi Muhammad bukan pula manusi suci

\subsection{Pengumpulan Data}

Dalam penelitian ini data sekunder diambil berdasarkan tweet berbahasa Indonesia yang menyinggung unsur SARA. Data dikumpulkan dengan cara crawling ke twitter, tool yang digunakan untuk proses data crawling adalah RapidMiner, dan operator yang digunakan adalah search twitter, search twitter digunakan sebagai penghubung ke akun twitter. Konektor twitter memungkinkan untuk dengan mudah mengakses data Twitter langsung dari RapidMiner Studio. Konektor dapat mencari frasa, tweet, atau informasi profil pengguna. Pada penelitian ini data yang dibutuhkan yaitu hanya tweet. Gambar 2 menunjukkan langkah crawling data tweet. 


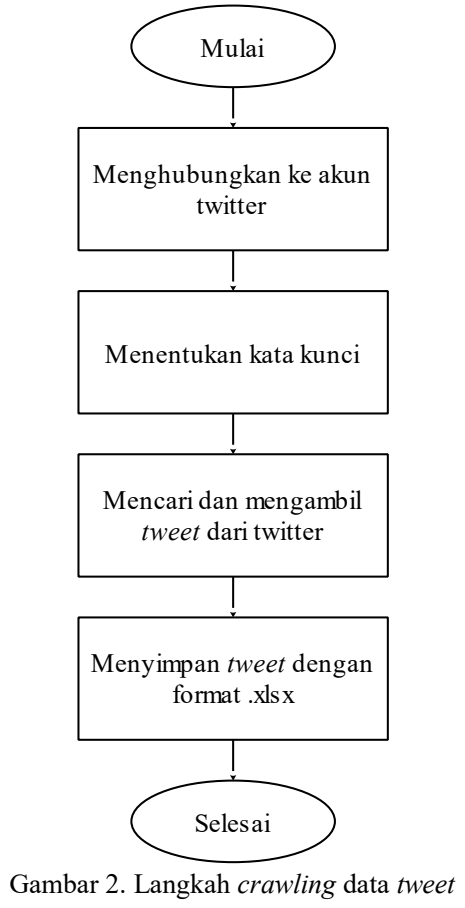

Berdasarkan Gambar 2, hal pertama yang harus dilakukan adalah menghubungkan ke akun twitter yang aktif untuk mendapatkan hak akses. Connector Twitter menggunakan mekanisme otentikasi yang disebut OAuth 2.0. Alih-alih memberikan RapidMiner nama pengguna dan kata sandi, maka akan menghasilkan token akses yang dapat digunakan oleh RapidMiner Studio untuk terhubung ke akun Twitter pengguna. Token ini tidak dapat digunakan oleh aplikasi lain dan membantu menjaga kredensial Twitter pengguna tetap aman.

Kemudian menentukan kata kunci, dalam penelitian ini menentukan kata kunci yang berkaitan dengan agama, ras, dan suku. Secara otomatis tool yang digunakan akan mencari data tweet berdasarkan kata kunci yang telah ditentukan. Terakhir yaitu menyimpan tweet yang talah didapatkan. Data tweet yang dikumpulkan disimpan dalam bentuk file bertipe .xlsx, agar data yang akan digunakan ke dalam RapidMiner pada read excel dapat terbaca dengan baik.

\subsection{Preprocessing Data}

Dalam proses ini data yang telah didapat dilakukan proses preprocesing untuk memilih data yang dapat digunakan dan menghilangkan data yang tidak diperlukan untuk tahap analisis. Tahapan yang dilakukan pada proses preprocesing ditunjukkan pada Gambar 3.

Langkah pertama pada tahap preprocessing adalah tokenisasi, tokenisasi merupakan suatu proses untuk memecahkan teks ke dalam bentuk kata. Data tweet yang sudah dipecah menjadi kata-kata kemudian diubah menjadi huruf kecil semua atau lowercase, langkah tersebut disebut dengan case normalization (Rozi, Arianto \& Hapsari, 2019). Kemudian kata yang sering muncul tetapi tidak memiliki pengaruh apapun dalam analisis sentimen harus dihilangkan, proses ini dinamakan stopword (Somantri dan Apriliani, 2018). Langkah terakhir pada preprocessing data adalah stemming, merupakan proses mengurangi imbuhan pada kata untuk bentuk kata dasar, jadi hasil akhir pada tahap preprocessing adalah tweet dalam bentuk kata-kata dasar.

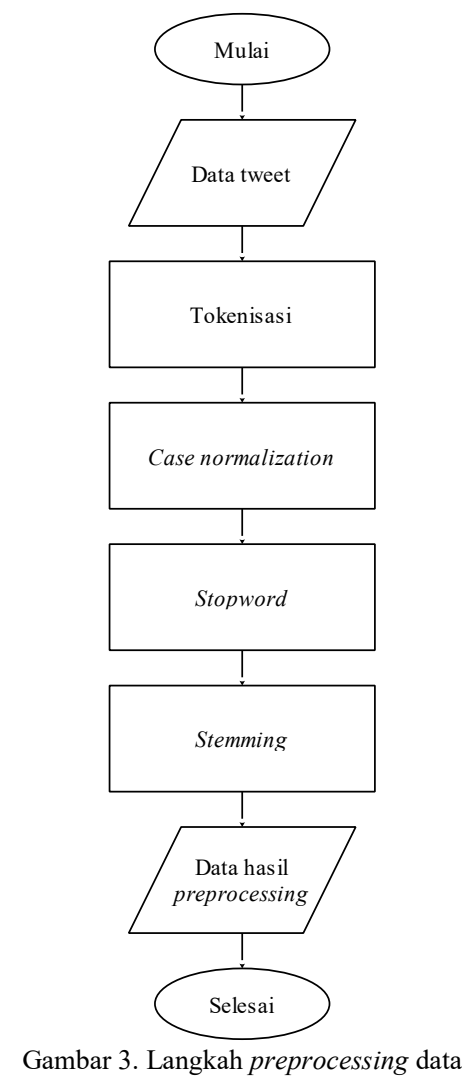

\subsection{Pembobotan Kata}

Proses pembobotan adalah proses merubah text ke bentuk numerik. Pada penelitian ini menggunakan term frequency-inverse document frequency (tf-idf). Algoritme TF-IDF adalah metode untuk membuat vektor kalimat berdasarkan frekuensi kata tersebut muncul (Ma dan Chen, 2019). Representasi dokumen tf-idf adalah skema pembobotan istilah umum dalam pengambilan informasi, yang juga telah ditemukan efektif untuk klasifikasi dokumen (Zhang, Yoshida \& Tang, 2011; Manevitz dan Yousef, 2001; Ke et al., 2011). Ini mewakili dokumen menggunakan vektor dengan dimensi sebagai ukuran kosa kata dari korpus dan elemen yang sesuai dengan bobot tf-idf dari setiap kata w dalam dokumen $\mathrm{d}$.

\subsection{K-Means Clustering}

Proses clustering untuk memberikan kelas pada sebuah kalimat pada tweet. Dalam proses ini menentukan kelas tiap kalimat menggunakan bantuan kamus dengan algoritma $k$-means untuk menentukan golongan kelas positif mengandung 
SARA atau negatif mengandung SARA. Langkahlangkah yang dilakukan pada $k$-means adalah inisialisasi dan iterasi (Duwairi dan Abu-Rahmeh, 2015; Gulnashin, Sharma \& Sharma, 2019). Proses inisialisasi dilakukan untuk menempatkan semua data tweet pada satu kelompok secara acak kemudian menghitung centroid sedangkan proses iterasi menghitung kembali jarak terpendek setiap data tweet secara berulang-ulang hingga centorid yang dihasilkan dalam iterasi saat ini tidak berubah atau sama dengan semua centroid yang dihasilkan pada iterasi sebelumnya.

\subsection{Klasifikasi}

Dalam proses klasifikasi digunakan algoritma Support Vector Machine (SVM). SVM bertujuan menemukan hyperplane (batas keputusan) terbaik yang memisahkan dua kelas yaitu positif mengandung SARA atau negatif mengandung SARA (Joachims, 1998; Gao, Cheng \& Yu, 2019). Batas hyperplane diukur dan titik maksimalnya diukur untuk menemukan pembagi dua kelas. Jarak yang memisahkan hyperplane pada dua kelas itulah yang disebut dengan batas, sedangkan istilah support vector merupakan data yang mimiliki jarak paling minimum dengan batas.

\subsection{Validasi dan Evaluasi}

Diperlukan dua metode, baik untuk mengklasifikasikan dan memprediksi tweet yang berisi SARA, yaitu validasi silang 5 kali lipat dan validasi silang 10 kali lipat. Validasi silang 5 kali lipat akan memproses data training dan testing sebanyak lima kali, sedangkan validasi silang $10 \mathrm{kali}$ lipat akan memproses data training dan testing sebanyak sepuluh kali Dilakukan proses tersebut untuk mendapatkan nilai akurasi yang tertinggi dalam proses pengujian. Pada proses evaluasi untuk mengukur dengan menggunakan tabel confusion matrix meliputi nilai akurasi, nilai precission, dan nilai recall pada tiap kelas tweet.

\subsection{Penarikan Kesimpulan}

Penarikan kesimpulan berdasarkan hasil kelas tweet positif mengandung SARA dan tweet negatif mengandung SARA yang didapat pada proses clustering $k$-means serta perhitungan evaluasi dengan menggunakan tabel confusion matrix meliputi nilai akurasi, nilai precission, dan nilai recall yang diperoleh berdasarkan algoritma Support Vector Machine (SVM). Gambar 4 menunjukkan seluruh proses pada penelitian ini.

\section{HASIL dan PEMBAHASAN}

Hasil dari preprocessing merupakan kata dasar yang penting dari masing-masing tweet, sedangkan hasil dari proses pembobotan merupakan bobot masing-masing kata pada masing-masing tweet.
Bobot pada masing-masing kata akan digunakan proses clustering, proses clustering menggunakan 2 cluster yang terdiri dari cluster 0 berarti positif SARA dan cluster 1 berarti negatif SARA. Hasil yang diperoleh pada proses ini antara lain cluster 0 berjumlah data 118 tweet dan cluster 1 berjumlah data 83 tweet.

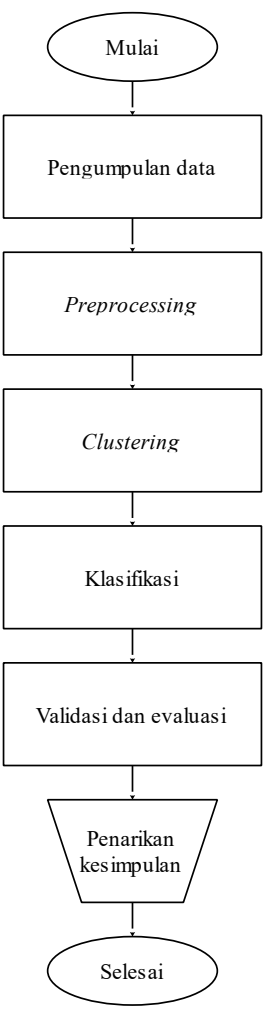

Gambar 4. Metode yang diusulkan

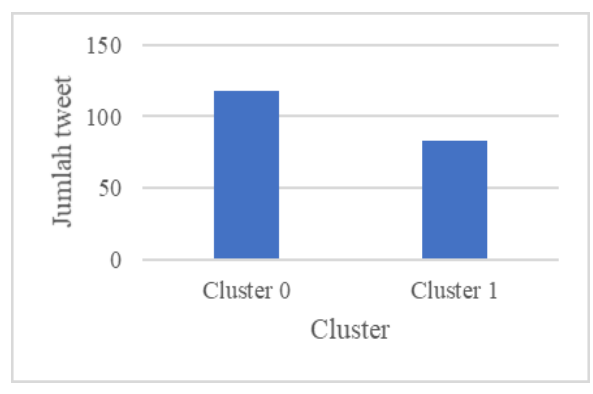

Gambar 5. Hasil proses clustering dengan K-means

Data yang telah diolah di clustering k-means diolah kembali untuk memperbaiki kelas tweet. Hasil clustering yang sudah didapatkan kemudian divalidasi oleh pakar bahasa, hasil yang diperoleh pada proses ini antara lain cluster 0 berjumlah data 139 tweet dan cluster 1 berjumlah data 62 tweet. Sedangkan berdasarkan Gambar 8, hasil proses clustering k-means, menunjukan cluster 0 memiliki hasil tweet terbanyak dibandingkan dengan cluster 1 sehingga sentimen tweet banyak mengandung unsur SARA. Berikut kalimat-kalimat yang menunjukkan perubahan cluster pada tweet seperti pada Tabel 2. 


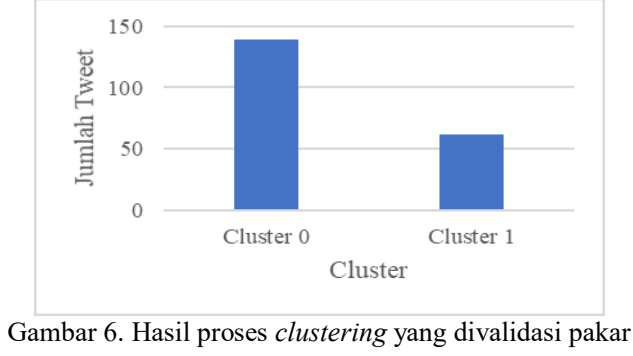

Untuk menggambarkan secara visualisasi kata apa yang dominan baik pada cluster 0 maupun cluster 1, peneliti mengunakan cloud word. Visualisasi Cloud Word pada masing-masing cluster dapat dilihat pada Gambar 9 dan 10. Terlihat jelas bahwa baik dari cluster 0 maupun cluster 1, kata yang paling dominan adalah mengenai agama, dan

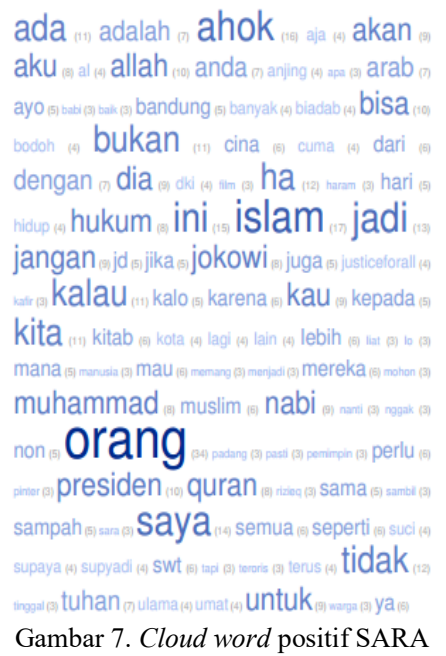

Data yang sudah menjadi kelompok, kelompok tweet yang mengandung SARA dan tweet yang tidak mengandung unsur SARA dilatih untuk menghasilkan pola dari kelas tersebut dengan menggunakan algoritme Support Vector Machine (SVM)

Proses klasifikasi algoritme support vector machine dengan memaksimalkan batas hyperplane. Konsep klasifikasi dengan support vector machine untuk mencari hyperplane terbaik yang berfungsi sebagai pemisah dua buah kelas data yaitu positif SARA dan negatif SARA.

Proses analisis tweet yang telah dilakukan pada proses pre-processing, clustering k-means, klasifikasi support vector machine, tahapan selanjutnya proses validasi dan evaluasi. Pada proses pengujian dilakukan proses validasi $k$-fold cross validation. Proses pengujian menggunakan 5-fold cross validation dan 10-fold cross validation. Berikut tabel confusion matrix pada 5-fold cross validation.

terutama agama yang paling disoroti pada kasus SARA adalah agama islam.

Tabel 2. Perubahan Cluster pada Tweet

\begin{tabular}{lcc}
\hline \multicolumn{1}{c}{ Tweet } & $\begin{array}{c}\text { Clustering } \\
\text { k-means }\end{array}$ & $\begin{array}{c}\text { Clustering } \\
\text { k-means }+ \\
\text { pakar }\end{array}$ \\
\hline $\begin{array}{l}\text { Siapa saja yang dukung } \\
\text { penista agama adalah } \\
\text { bajingan yang perlu diludahi } \\
\text { mukanya }\end{array}$ & Negatif & Positif \\
\hline $\begin{array}{l}\text { Allah kan bukan orang } \\
\text { Arab. Tentu Allah senang } \\
\text { kalau aya-ayatNya dibaca } \\
\text { dg gaya Minang, Ambon, } \\
\text { Cina, Hiphop }\end{array}$ & Negatif & Positif \\
\hline $\begin{array}{l}\text { Ngajari at ngajak org Sunda } \\
\text { ngaji, it sama aja, ngajari } \\
\text { anjing menggonggong }\end{array}$ & Negatif & Positif \\
\hline
\end{tabular}

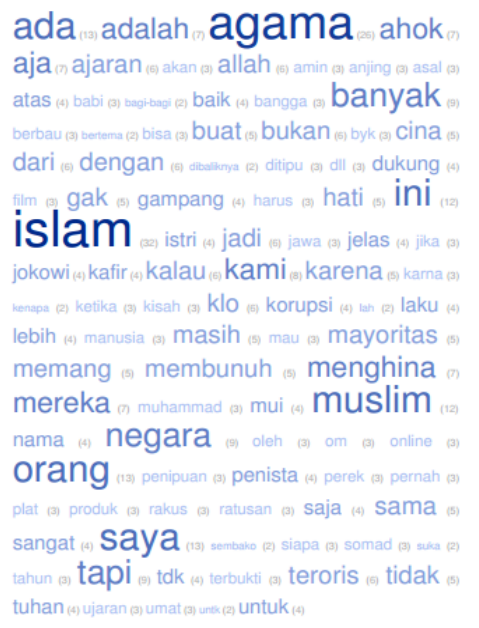

Gambar 8. Cloud word negatif SARA

Tabel 3. Confusion Matrix 5-Fold Cross Validation.

\begin{tabular}{lcc}
\hline & True positif SARA & $\begin{array}{c}\text { True negatif } \\
\text { SARA }\end{array}$ \\
\hline Pred. positif SARA & 117 & 71 \\
Pred. negatif SARA & 1 & 12 \\
\hline
\end{tabular}

Berdasarkan Tabel 3 evaluasi dengan menggunakan confusion matrix menghasilkan perhitungan precision, recall, F-measure, dan accuracy. Hasil perhitungan yang diperoleh dengan menggunakan confusion matrix disajikan dalam Tabel 4 sebagai berikut:

Tabel 4. Performa Confusion Matrix 5-Fold Cross Validation

\begin{tabular}{lc}
\hline \multicolumn{1}{c}{ Performa } & Nilai \\
\hline Precision & $62,23 \%$ \\
Recall & $99,15 \%$ \\
F-measure & $76,46 \%$ \\
Accuracy & $64,18 \%$ \\
\hline
\end{tabular}

Data yang telah diolah di clustering $k$-means 5fold cross validation diolah kembali dengan divalidasi oleh pakar bahasa untuk memperbaiki hasil kelas tiap tweet. Hasil yang diperoleh dari proses tersebut disajikan pada Tabel 5 sebagai berikut: 
Tabel 5. Confusion Matrix 5-Fold Cross Validation dan Validasi

\begin{tabular}{lcc} 
& \multicolumn{2}{c}{ Pakar } \\
& $\begin{array}{l}\text { True positif } \\
\text { SARA }\end{array}$ & $\begin{array}{l}\text { True negatif } \\
\text { SARA }\end{array}$ \\
\hline $\begin{array}{l}\text { Pred. positif } \\
\text { SARA }\end{array}$ & 139 & 60 \\
$\begin{array}{l}\text { Pred. negatif } \\
\text { SARA }\end{array}$ & 0 & 2 \\
\hline
\end{tabular}

Berdasarkan tabel 5 evaluasi dengan menggunakan confusion matrix menghasilkan precision, recall, F-measure, dan accuracy. Hasil perhitungan yang diperoleh dengan menggunakan confusion matrix disajikan dalam Tabel 6 sebagai berikut:

Tabel 6. Performa Confusion Matrix 5-fold Cross Validation Dan Validasi Pakar

\begin{tabular}{ll}
\hline \multicolumn{1}{c}{ Performa } & \multicolumn{1}{c}{ Nilai } \\
\hline Precision & $69,85 \%$ \\
Recall & $100 \%$ \\
F-measure & $82,24 \%$ \\
Accuracy & $70,15 \%$ \\
\hline
\end{tabular}

Selanjutnya $k$-fold cross validation yang digunakan adalah 10 . Berikut tabel confusion matrix pada 10-fold cross validation.

\begin{tabular}{lcc}
\multicolumn{2}{c}{ Tabel 7. Confusion Matrix } & 10-Fold Cross Validation \\
\hline & $\begin{array}{l}\text { True positif } \\
\text { SARA }\end{array}$ & $\begin{array}{l}\text { True negatif } \\
\text { SARA }\end{array}$ \\
\hline $\begin{array}{l}\text { Pred. positif } \\
\text { SARA } \\
\text { Pred. negatif }\end{array}$ & 117 & 72 \\
SARA & 1 & 11 \\
\hline
\end{tabular}

Berdasarkan Tabel 7 evaluasi dengan menggunakan confusion matrix menghasilkan perhitungan precision, recall, F-measure, dan accuracy. Hasil perhitungan yang diperoleh dengan menggunakan confusion matrix disajikan dalam Tabel 8 sebagai berikut:
Tabel 8. Performa Confusion Matrix 10-Fold Cross Validation

\begin{tabular}{ll}
\hline \multicolumn{1}{c}{ Performa } & Nilai \\
\hline Precision & $61,90 \%$ \\
Recall & $99,15 \%$ \\
F-measure & $76,21 \%$ \\
Accuracy & $63,68 \%$ \\
\hline
\end{tabular}

Data yang telah diolah di clustering $k$-means 10 fold cross validation diolah kembali dengan divalidasi oleh pakar bahasa untuk memperbaiki hasil kelas tiap tweet. Hasil yang diperoleh dari proses tersebut disajikan pada Tabel 9 sebagai berikut:

\begin{tabular}{lcc} 
Tabel 9. Confusion Matrix & 10-Fold Cross & Validation Dan Manual \\
& $\begin{array}{l}\text { True positif } \\
\text { SARA }\end{array}$ & $\begin{array}{l}\text { True } \\
\text { negatif } \\
\text { SARA }\end{array}$ \\
\hline $\begin{array}{l}\text { Pred. positif } \\
\text { SARA }\end{array}$ & 139 & 58 \\
$\begin{array}{l}\text { Pred. negatif } \\
\text { SARA }\end{array}$ & 0 & 4 \\
\hline
\end{tabular}

Berdasarkan tabel 9 evaluasi dengan menggunakan confusion matrix menghasilkan perhitungan precision, recall, F-measure, dan accuracy. Hasil perhitungan yang diperoleh dengan menggunakan confusion matrix disajikan dalam tabel 10 sebagai berikut:

\begin{tabular}{|c|c|}
\hline Performa & Nilai \\
\hline Precision & $70,56 \%$ \\
\hline Recall & $100 \%$ \\
\hline$F$-measure & $82,74 \%$ \\
\hline Accuracy & $71,14 \%$ \\
\hline
\end{tabular}

Berdasarkan hasil analisis yang telah dilakukan maka untuk mengevaluasi model yang diperoleh dari hasil ekperimen didapatkan sebagai berikut:

Tabel 1. Performa Confusion Matrix 10-Fold Cross Validation Dan Validasi Pakar

\begin{tabular}{llllll}
\hline K-Fold Cross Validation & \multicolumn{1}{c}{ Model } & Precision & \multicolumn{1}{c}{ Recall } & F-measure & Akurasi \\
\hline 5-Fold Cross Validation & K-means + SVM & $62,23 \%$ & $99,15 \%$ & $76,18 \%$ & $64,18 \%$ \\
& K-means + validasi pakar + SVM & $69,85 \%$ & $100 \%$ & $82,24 \%$ & $70,15 \%$ \\
\multirow{3}{*}{ 10-Fold Cross Validation } & K-means + SVM & $61,90 \%$ & $99,15 \%$ & $76,21 \%$ & $63,68 \%$ \\
& K-means + validasi pakar + SVM & $70,56 \%$ & $100 \%$ & $82,74 \%$ & $71,14 \%$ \\
\hline
\end{tabular}

Dari hasil Tabel 10 diperlihatkan bahwa setelah dilakukan eksperimen terdapat perbedaan antara model dari k-means $+S V M$ dibandingkan dengan model $k$-means + validasi pakar + SVM mengalami peningkatan. Tabel 10 menunjukkan hasil nilai precision tertinggi sebesar $70,56 \%$ pada model $k$ means + validasi pakar + SVM 10-fold cross validation, nilai recall tertinggi sebesar $100 \%$ pada model $k$-means + validasi pakar + SVM 5-fold cross validation dan k-means + validasi pakar + SVM 10fold cross validation, nilai f-measure tertinggi sebesar $82,74 \%$ pada model k-means + validasi pakar + SVM 10-fold cross validation, dan nilai akurasi tertinggi sebesar $71,14 \%$ pada model $k$ means + validasi pakar + SVM 10-fold cross validation.

Simulasi atau prototype digunakan untuk mendukung hasil preprocessing dan hasil prediksi kelas dengan memasukan tweet yang ingin diseleksi. Seperti pada Gambar 9. 


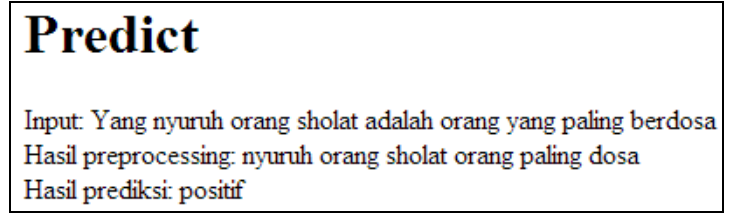

Gambar 9. Simulasi prediksi

\section{KESIMPULAN}

Berdasarkan hasil dari penelitian yang telah dilakukan, Kombinasi $k$-means dan support vector machine (SVM) sudah berhasil untuk menganalisis tweet yang positif mengandung SARA dan tweet yang negatif mengandung SARA akan tetapi Hasil pengelompokan tweet yang mengandung SARA dan tidak mengandung SARA belum memiliki hasil yang baik, dibuktikan dengan hasil klasifikasi menggunakan algoritme SVM masih rendah. Setelah proses pengelompokan diperbaiki dengan validasi pakar bahasa, hasil akurasi dari proses klasifikasi dapat meningkat baik dengan 5-fold cross validation maupun 10-fold cross validation. Sehingga untuk penelitian selanjutnya perlu adanya perbaikan metode yang disulkan untuk memperoleh hasil yang lebih akurat, baik dalam mengelompokan dan klasifikasi data twitter yang mengandung unsur SARA dan tidak mengandung unsur SARA. Selain itu, sebaiknya dibangun sistem yang dapat diterapkan untuk menganalisis konten twitter.

\section{DAFTAR PUSTAKA}

DUWAIRI, R. dan ABU-RAHMEH, M., 2015. A novel approach for initializing the spherical K-means clustering algorithm. Simulation Modelling Practice and Theory, [online] 54, pp.49-63. Available at: $<$ http://dx.doi.org/10.1016/j.simpat.2015.03 $.007>$.

GAO, J., CHENG, Q. \& YU, P.L.H., 2019. Detecting Comments Showing Risk for Suicide in YouTube. In: Proceedings of the Future Technologies Conference. [online] Springer, Cham, pp.385-400. Available at: $<$ http://link.springer.com/10.1007/978-3030-02683-7>.

GARAY, J., YAP, R. \& SABELLANO, M.J., 2019. An analysis on the insights of the antivaccine movement from social media posts using k-means clustering algorithm and VADER sentiment analyzer. IOP Conference Series: Materials Science and Engineering, 482, pp.1-6.

GULNASHIN, F., SHARMA, I. \& SHARMA, H., 2019. Progress in Advanced Computing and Intelligent Engineering. Progress in Advanced Computing and Intelligent Engineering, [online] 714, pp.149-155. Available
$<$ http://link.springer.com/10.1007/978-98113-0224-4>.

HAN, J., KAMBER, M. \& PEI, J., 2012. Data mining: concepts and techniques. Third Edit ed. [online] Vasa. London, UK: Morgan Kaufmann. Available at: $<$ http://medcontent.metapress.com/index/A 65RM03P4874243N.pdf $>$.

HOOTSUITE dan WE ARE SOCIAL, 2018. Essential Insights Into Internet, Social Media, Mobile, and E-Commerce Use Around The World. [online] Digital in 2018. Available at: $<$ https://wearesocial.com/blog/2018/01/glo bal-digital-report-2018> [Accessed 25 Jun. 2018].

JOACHIMS, T., 1998. Text Categorization with Support Vector Machines: Learning with Many Relevant Features. In: European Conference on Machine Learning. [online] pp.137-142. Available at: $<$ http://www.springerlink.com/index/drhq5 81108850171.pdf $>$.

KE, B., SHEN, X.D., JI, H., GAO, F., KAMO, N., ZHAI, Y., BUSUTTIL, R. V \& KUPIECWEGLINSKI, J.W., 2011. STAT3-PTEN Axis: A Negative Regulator of Dendric Cell-Mediated Innate Immune Functions. American Journal of Transplantation, 11, p. 197.

KEMENTERIAN KOMUNIKASI DAN INFORMATIKA, 2017. Ujaran Kebencian Picu Generasi Muda Jadi Intoleran dan Diskriminatif. Jakarta.

KOROVKINAS, K., DANĖNAS, P. \& GARŠVA, G., 2019. SVM and k-Means Hybrid Method for Textual Data Sentiment Analysis. Baltic Journal of Modern Computing, 7(1).

LIU, B., 2012. Sentiment Analysis and Opinion Mining. Synthesis Lectures on Human Language Technologies, [online] 5(1), pp.1-167. Available at: $<$ http://www.morganclaypool.com/doi/abs/ 10.2200/S00416ED1V01Y201204HLT016 $>$.

LIU, S. dan LEE, I., 2018. Email Sentiment Analysis Through k-Means Labeling and Support Vector Machine Classification. Cybernetics and Systems, 49(3), pp.181199.

MA, S. dan CHEN, X., 2019. A data mining approach to predict risk of cardiovascular A Data Mining Approach to Predict Risk of Cardiovascular. In: AIP Conference Proceedings. pp.020014-1-020014-7.

MANEVITZ, L.M. dan YOUSEF, M., 2001. OneClass SVMs for Document Classification. 
Journal of Machine Learning Research 2, 2, pp.139-154.

MEDHAT, W., HASSAN, A. \& KORASHY, H., 2014. Sentiment analysis algorithms and applications: A survey. Ain Shams Engineering Journal, [online] 5(4), pp.1093-1113. Available at: $<$ http://dx.doi.org/10.1016/j.asej.2014.04.0 $11>$.

MUSTAKIM, 2012. Pemetaan Digital dan Pengelompokan Lahan Hijau di Wilayah Provinsi Riau Berdasarkan Knoledge Discovery in Databases (KDD) dengan Teknik K-Means Mining. In: Seminar nasional Teknologi Informasi Komunikasi dan Industri (SNTIKI. Pekanbaru, Riau: Fakultas Sains dan Teknologi UIN Sultan Syarif Kasim Riau, pp.103-111.

MUZAKIR, A., 2014. Analisa Dan Pemanfaatan Algoritma K-Means Clustering pada Data Nilai Siswa sebagai Penentuan Penerimaan Beasiswa. In: Prosiding Seminar Nasional Aplikasi Sains \& Teknologi (SNAST). Yogyakarta: Institut Sains \& Teknologi Yogyakarta, p.A-195-A-200.

PRASETYO, E., 2014. Data Mining, Mengolah Data Menjadi Informasi Menggunakan Matlab. 1st Publis ed. Yogyakarta: Andi Offset.

RAHMAWATI, A., MARJUNI, A. \& ZENIARJA, J., 2017. Analisis Sentimen Publik Pada Media Sosial Twitter Terhadap Pelaksanaan Pilkada Serentak Menggunakan Algoritma Support Vector Machine. CCIT Journal, [online] 10(2), pp.197-206. Available at: $<$ http://ejournal.raharja.ac.id/index.php/ccit /article/view/67>.

ROZI, N.F., ARIANTO, F. \& HAPSARI, D.P., 2019. Analisis Sentimen Pada Opini Pengguna Maskapai Penerbangan Sentiment Analysis on Passenger Opinions At Airlines Company. Jurnal Teknologi Informasi dan Ilmu Komputer (JTIIK), [online] 6(3), pp.321-326. Available at: $<$ http://jtiik.ub.ac.id/index.php/jtiik/article/ view/1337/pdf $>$.

RUDYBYO, 2011. Pengertian Sara: Suku, Ras, Agama, dan Antaragama. [online] Available at: $<$ http://rudybyo.blogspot.co.id/2011/04/pen gertian-sara-suku-ras-agama-dan.html> [Accessed 10 Oct. 2018].

SOMANTRI, O. dan APRILIANI, D., 2018. Support Vector Machine Berbasis Feature Selection Untuk Sentiment Analysis Kepuasan Pelanggan Terhadap Pelayanan Support Vector Machine Based on Feature
Selection for Sentiment Analysis Customer Satisfaction on Culinary. Jurnal Teknologi Informasi dan Ilmu Komputer (JTIIK), [online] 5(5), pp.537-548. Available at: $<$ http://jtiik.ub.ac.id/index.php/jtiik/article/ view $/ 867 / \mathrm{pdf}>$.

SOMANTRI, O., WIYONO, S. \& DAIROH, , 2016. Metode K-Means untuk Optimasi Klasifikasi Tema Tugas Akhir Mahasiswa Menggunakan Support Vector Machine (SVM). Scientific Journal of Informatics Universitas Negeri Semarang, 3, pp.34-45.

TIM PUSAT HUMAS KEMENTERIAN PERDAGANGAN RI, 2014. Panduan Optimalisasi Media Sosial untuk Kementerian Perdagangan RI. [online] Tim Pusat Humas Kementerian Perdagangan RI. Available

at: $<$ http://www.kemendag.go.id/files/pdf/2015 /01/15/buku-media-sosial-kementerian-ido1421300830.pdf $>$ [Accessed 21 May 2018].

XU, D. dan TIAN, Y., 2015. A Comprehensive Survey of Clustering Algorithms. Annals of Data Science, 2(2), pp.165-193.

ZHANG, W., YOSHIDA, T. \& TANG, X., 2011. A comparative study of $\mathrm{TF}^{*} \mathrm{IDF}$, LSI and multi-words for text classification. Expert Systems with Applications, [online] 38(3), pp.2758-2765. Available at: $<$ http://dx.doi.org/10.1016/j.eswa.2010.08.0 $66>$. 
Halaman ini sengaja dikosongkan 